\title{
The Settlement of Consumer Disputes by Virtual Mediation Particularly on Banking and Buying Services Online
}

\author{
Marulak Pardede ${ }^{1, *}$ Henry Donald Lbn Toruan ${ }^{1}$ Mosgan Situmorang ${ }^{1}$ \\ Syprianus Aristeus ${ }^{1}$
}

${ }^{1}$ The Agency for Research and Development of Law and Human Rights of the Ministry of Law and Human Rights
of The Republic of Indonesia, Jakarta, Indonesia
${ }^{*}$ Corresponding author. Email: marulakp@yahoo.com

\begin{abstract}
The increasingly massive spread of the Coronavirus Dissease 2019 (COVID-19) virus in Indonesia has led the government to adopt a large-scale social restrictions (PSBB) policy in a sustainable manner. This policy limits human mobilization as an effort to break the chain of spreading Covid-19. Community movement was limited by being asked to stay at home. For offices, both private and government, apply working from home for some employees. Limit movements due to concerns over the Covid 19 virus have made most people shop for home needs online. According to Analytic Data Advertising (ADA), online shopping activities have increased by $400 \%$ since March 2020 due to this pandemic. Bank Indonesia (BI) noted, purchase transactions via e-commerce in March 2020 reached 98.3 million transactions. That figure is an increase of $18.1 \%$ compared to February. Not only that, the total value of e commerce transactions also increased by 9.9\% to IDR 20.7 trillion from February 2020. In today's digital era, people easily make virtual transactions in shopping, for example cash on delivery (COD), e. -wallets, joint accounts, transfers, and credit cards. The ease of virtual transactions is very helpful for people to get their daily needs by shopping online without leaving the house. They only make payments by wire transfer or credit card via bank or marketplace applications. However, the convenience of shopping online has been abused by many traders by committing fraud such as ordering goods that do not match the image or what has been promised. Even the form of fraud that often occurs is what is called phishing, which is tricking the target with the intention of stealing the target's account, such as website forgery and online registration. Then account abuse through One Time Password (OTP) is carried out by hijacking consumer accounts so that the criminals use them to shop. The question is, can virtual mediation be done in resolving legal issues between consumers and banks and online sellers? The purpose of this paper is to provide an idea of the use of virtual mediation in resolving consumer protection disputes in the era of the Covid 19 pandemic.
\end{abstract}

Keywords: dispute resolution, consumer, virtual mediation.

\section{INTRODUCTION}

Since the World Health Organization (WHO) announced the status of a global pandemic for Covid-19, things have changed. The Covid-19

Online shopping.[1] The shift in people's shopping styles from off line to on line during the Covid 19 pandemic was supported by an increase in internet ownership by the public. based on data there are currently 143 million people using internet or 64 percent of the total population and the digital users outbreak seems to have forced society to shift to the era of digitalization. Technology plays an important role here, where people can use the internet to interact. Even to meet their daily needs, people can get it by buying online or commonly known as

has increased since the pandemic, many people are now shopping online.[2] According to Analytic Data Advertising (ADA), online shopping activities have increased by $400 \%$ since March 2020 due to this pandemic. Bank Indonesia (BI) noted the transactions via e-commerce in March 2020 reached 
98.3 million . it increase $18.1 \%$ compared to February. furthermore, the total value of ecommerce transactions also increased by $9.9 \%$ to IDR 20.7 trillion from February 2020. Recently, In digital era, people easily make virtual transactions in shopping, for example cash on delivery (COD), e. -wallets, joint accounts, transfers, and credit cards.[3]

However, the increasing public interest in online shopping during this pandemic was actually used as a part of the seller to get profits in various ways. The Ministry of Trade (Kemendag) has just blocked 321 accounts of online seller who is selling low-quality medical devices (medical equipment) and basic necessities at very high prices. In addition to taking action against traffickers, the Ministry of Trade also provides a forum for people who have been disadvantaged when shopping online. However, since 2018 or last 2 years, there had 127 complaints received. Naughty seller accounts Blocked, the Ministry of Trade is ssessed as Less Firm. In fact, the public can submit a complaint if they encounter practices, including purchasing goods that are not in accordance with the agreement (goods that arrive are different from those shown in advertisements); goods purchased do not arrive (not yet received by consumers); items that are damaged / cannot be used. Not only that, the issue of unilateral cancellation carried out by business actors; the time of arrival of the goods is not as promised; a very long refund (refund); and experiencing fraud in the local marketplace system that causes losses to consumers can also be reported to the agency [4]. Meanwhile, the problems that are often reported to the Indonesian Consumers Foundation (YLKI) are orders for goods that have not arrived, defective products, difficulties in the process of returning goods, to the process of refunding or returning money.[5]

The development of information technology in ecommerce trade has really helped people shop during the Covid-19 pandemic. However, the convenience of shopping online will cause legal problems if it is not followed by a security system for transactions on the internet, because it opens up loopholes for fraudsters to break into password accounts that result in consumer losses. Based on data from the National Consumer Protection Agency (BPKN), from January to May 2020, there was 70 complaints about losses in e-commerce transactions. Most of the e commerce complaints are related to phishing and One Time Password (OTP). In a phishing complaint, a seller on the e-commerce platform sends a link that resembles the platform's website by calling the consumer's personal telephone number. Another mode, namely by manipulating so that the customer sends an OTP, which allows other people to make transactions with the account.[3] OTP is a password that can validate an attempt to log into an account or to do it only once. OTP aims to avoid the weaknesses of static password-based authentication systems. In its implementation, OTP is also combined with two-factor authentication. OTP also requires access to devices that are only owned and only known by the account owner. Currently, most institutions using OTP send passwords via smartphones, either via popup notifications, or the most commonly found, namely through text messages or Short Message Service (SMS). Unfortunately, the security system still has a gap, because criminals can infiltrate malware with the ability to monitor and steal data on the cellphone without realizing it through messages containing malicious links or phishing.[6]

Today's information and communication technology has been utilized in the social life of the community, and has entered various sectors of life, including the government sector, the business sector, banking, education, health and personal life. The benefits of information and communication technology, apart from having a positive impact, are also recognized as providing opportunities to be used as a means of committing new crimes (cyber crime) so that protection efforts are needed. Thus, it can be said that information and communication technology is like a double-edged sword, where in addition to making a positive contribution to the improvement of human welfare, progress and civilization, it is also a potential and effective means of carrying out acts against the law.[7] Therefore, the problem in this paper is how to regulate legal protection in buying and selling online and how are the dispute resolution mechanisms that consumers?

\section{RESEARCH METHODS}

This research used a normative juridical approach which is descriptive analysis in which the authors compiled the research by explaining and analyzing the provisions of legislation that were adjusted to current conditions or phenomena. The study used secondary data sources consisting of primary legal materials, namely the Civil Code, Law Number 19 Year 2016 concerning Amendments to Law Number 11 of 2008 concerning Information and Electronic Transactions, Law Number 7 of 2014 concerning Trade, Act Number 10 of 1998 concerning Banking, Act Number 8 of 1999 concerning Consumer Protection, Law No. 30 of 
1999 concerning Arbitration and Alternative Dispute Resolution, Government Regulation Number 80 of 2019 concerning Trade Through Electronic Systems, Supreme Court Regulation No. 4 of 2019 concerning Amendments to the Regulation of the Supreme Court Number 2 of 2015 concerning Procedures for Settlement of Simple Lawsuits, Supreme Court Regulation Number 3 of 2018 concerning Case Administration in the Court Electronic Perma No. 3 of 2018 concerning Electronic Court Case Administration, Financial Services Authority Regulation Number 1 of 2013 concerning Financial Services Sector Consumer Protection, Financial Services Authority Regulation Number 1/ POJK.07 / 2014 concerning Alternative Institutions for Dispute Resolution in the Financial Services Sector. Then, secondary legal materials in the form of literature books and mass media news. In pandemic conditions, data collection techniques are carried out online with data analysis techniques starting from collecting, sorting data, displaying data and drawing conclusions on these data so that an analysis is created in this study.

\section{FINDING AND DISCUSSION}

\subsection{Terms and Definitions}

There are several terms that usually used in online commerce such as marketplaces, online shops and e-commerce. Marketplace is a business model where the website is concerned not only to help promote merchandise, but also to facilitate online money transactions. In this online shopping system, a website provides land or a place for sellers to sell their products. It is on this website that we will find products from different sellers, there are also several sellers from online shops. Each product contained on the website has been given specifications and an explanation of the condition of the product, so that buyers can immediately click the "buy" button and then transfer the amount listed. In shopping system, the seller does not ask and answer questions to the buyer and there are no discounts or bargains like in an online shop. Examples of marketplaces include tokopedia.com, olx.co.id, Bukalapak.com, etc.[8] One of the first marketplaces in the world to popularize the marketplace was e-Bay. Released in 1995, this website made the selling process easier and more efficient. Two decades later, the marketplace has grown a lot and now you can find marketplaces for everything from used goods to food.[9]

While an online shop is a place where a sale of goods or services occurs on the internet. An online shop does not have to be on a website but can open an online shop on social media such as Facebook and Instagram.[9] an online shop is an online shopping system where buyers can ask the seller directly for prices or any questions related to products, either via BBM, LINE, or Whatsapp. In some online shops, usually there will be a discount after buyers often subscribe to the online shop.[8] The availability of various kinds of consumer needs in the marketplace really helps consumers to buy their needs through online shopping during the Covid-19 pandemic.

The use of the term Electronic Commerce or abbreviated as E-Commerce is now increasingly being used by the public as a technical term in business. In general, the meaning of E-commerce (electronic commerce) is the activity of buying and selling goods / services or transmitting funds / data via electronic networks, especially the internet. With the development of information technology and software, making conventional transactions possible to do electronically. Website is used as a substitute for offline store. E-commerce websites include various functions such as product storefronts, online ordering and stock inventory, to carry out their primary function as e-commerce. The software used is installed on an e-commerce server and works simultaneously with an online payment system to process transactions.[10]

Quayle defines E-Commerce as a sharing form of electronic data exchange or Electronic Data Interchange (EDI) that involves sellers and buyers via mobile devices, E-Mail, mobile connected devices, on the internet and intranet networks. Furthermore, Chaffey defines E-Commerce as all forms of information exchange processes between organizations and stakeholders based on electronic media connected to the network.[11]

In addition to the terms mentioned above, there is another term known as E-Business, which is a business process related to information systems. The E-Business method allows companies to connect and access internal and external data in a more efficient and fle xible process, to better engage with suppliers and business partners, and to better satisfy customer wants and expectations.[12] E-Business involves the entire value chain in business processes, namely electronic purchasing and supply chain management, processing orders electronically, managing services, and working with business partners.[12]

These various forms of trade use information technology as a medium for offering merchandise. 
But in their selling activities, the three of them have different places to sell and marketing strategies.

\subsection{E-Commerce Transactions}

There are four types of transaction categories in E-Commerce,[11] namely:

\section{E-Commerce Business to Business (B2B)}

E-Commerce Business to Business (B2B) is a form of online E-Commerce interaction that occurs between producers (companies, home industries, providers of goods and services) and distributors (suppliers) and retailers. These distributors and retailers then distribute the product to their respective consumers. This form of interaction is general in nature and does not directly interact with the end consumers who need these goods and services. In the Business to Business (BSB) process, activities include Supply Chain, information exchange, operational management, and others.

2. E-Commerce Retail or Business to Customer (B2C)

Retail or Business to Customer (B2C) is a part of E-Commerce which emphasizes the process of ordering, buying and selling products or via internet access. This means that sellers and buyers can directly meet and interact electronically and online, taking advantage of the features provided. Suppose a virtual shopping cart and electronic payment using credit cards and so on.

E-Commerce Retail or Business to Customer (B2C) which is conducted online, involves actors in the form of customers, business organizations, and websites. In Business Organizations and Websites, there is a buying and selling transaction process in the form of online order processing (Order Processing). From the Customer to the Website there is an order, which states the conditions under which the consumer can place an order for the desired product (Order) online.[13]

\section{E-Commerce Customer to Business (C2B)}

E-Commerce Customer to Business (C2B) is a form of E-Commerce which is the opposite of ECommerce in general, where consumers play an active role by informing the internet audience about their needs, for then one or more companies or product and service services will be trying to offer products and services to meet these needs.

There are three components to E-Commerce Customer to Business (C2B), namely Website, Business Organization, and Customer. Customers place orders (products or services) through the available website services, where the website includes a variety of choices at their respective prices. The customer then places an order (Order) via the website. The order is then processed by the Business Organization that provides the goods or services ordered by the Customer. Customers did electronic payments directly to the Business Organization. soon payment is received, the Business Organization will send the ordered goods to the Customer.

\section{E-Commerce Customer to Customer (C2C)}

C2C type e-Commerce emerged as a result of advances in website technology, so that users can interact with each other and content is provided (Generate) by the users themselves. This form of active interaction also affects the form of ECommerce that occurs. At E-Commerce Customer to Customer (C2C), an E-Commerce website is available where users can sell products and services on the website, as well as search for the products and services they want and make transactions.

The $\mathrm{C} 2 \mathrm{C}$ (Consumer to Consumer) Business Model between consumers and consumers, this is the core of the $\mathrm{C} 2 \mathrm{C}$ business model. This business activity generally involves individuals. An individual consumer sells goods or services to other consumers. Due to the small capital, this business model is also very popular. This B2C (Business to Consumer) Business Model is the most common business model found in the e-commerce market. As the name implies, this business model involves a business which in this case is producers and consumers. For this reason, this B2C model resembles a traditional retail model. forexample an online shop. As the name implies, this B2B (Business to Business) business model occurs between business and business. The seller only focuses on the business market and does not serve orders from consumers. Generally, this B2B business model is more dominated by service providers. However, some are providers of goods.

The four forms of e-commerce as mentioned above are the most commonly used by the public in online transactions. However, the Retail or Business to Customer (B2C) model that is most widely used by the public in buying and selling transactions online with peddlers who are members of the marketplace or online shop. 


\subsection{Consumer Legal Protection in Online Buying and Selling}

Many experts distinguish between "agreement" and "contract". One of the distinguishing experts is Subekti according to which a written agreement or agreement can be called a "contract". While the agreement does not have to be done in writing, but can be done orally. That the opinion is actually debatable, because the terms agreement and contract are essentially "the same". As is well known, the Civil Code is a product of Dutch colonial heritage which uses the term "overrenkomst" which in English is defined as "contract". So, if "overrenkomst" which in Indonesian is only defined as "agreement" and not defined as "contract", then it can be said to be inaccurate, because agreement and contract have the same meaning when translated into Indonesian.[14] J. Satrio in his book says that Chapter II Book III is entitled "An engagement born from a contract or agreement". The use of the word "or" between "contracts" showsthe words "agreement" and "contract" according to Book III Burgerlijk Wetboek (BW) are the same and the way they used consecutively as mentioned above is intentional for the purpose of showing, that the legislators consider the two terms to have the same meaning.[15] The author also agrees with the above thought which equates the meaning of agreement and contract.

Related to online buying and selling, there are also those who use the term online contract to describe buying and selling carried out through a network of informatics systems. The term online contract is used by the Dean of the Faculty of Law, University of Indonesia and Lecturer in the field of Intellectual Property \& Telematics, Edmon Makarim, which means the same as electronic contracts, namely legal bonds or relationships that are carried out electronically that combine networks of computer-based information systems with systems. Buying and selling online was born because of the sale and purchase contract that occurs electronically between the seller and the buyer. However, until now the rules for buying and selling electronics are still not clearly written in the applicable law in Indonesia. This is because the legal terms of the agreement electronically have not been specifically regulated.[16]

However, in Article 1320 the legislators provide a general benchmark for how an agreement is born. it determines what actions a person must perform, therefore the parties can legally give birth to rights and obligations for them or the third party.[15] The conditions for the validity of an agreement according to Article 1320 of the Civil Code are:

1. To agree with those who bind themselves;

2. The ability to make an engagement;

3. A certain thing;

4. A cause that is lawful.

The 1 st and 2 nd conditions are referred to as subjective conditions, if not fulfilled, one of the parties can request the cancellation of the agreement that has been made. The 3rd and 4rd conditions are called objective conditions which if not fulfilled will result in the agreement being null and void. Cancellation can be divided into 2 terms that have juridical consequences, namely:

a. Null and Void; From the beginning, the agreement has been canceled, or is considered never to exist, if the objective conditions are not met. The agreement is null and void, from the beginning there was never an agreement

b. Voidable; If one of the subjective conditions is not fulfilled, the agreement is not automatically null and void, but one of the parties can request the cancellation to the court. The agreement itself remain binding on both parties, as long as it is not canceled by the judge.[17]

An agreement between two or more parties gives birth to rights and obligations to each party so that if one of the parties does not fulfill its obligations it is considered as default. Default can be interpreted as an act of the parties in the sale and purchase agreement that is not in accordance with the agreement between the parties, either violating the agreement, for example the producer sends goods ordered by consumers that do not match what is stated in the description of the picture, or according to the picture but there are defects that are not delivered before, or not implementing the agreement, for example the consumer has paid for the goods ordered but the producer does not send the goods immediately or delays delivery or does not even deliver the goods.[18]

In the sale and purchase contract the actors involved have different rights and obligations, the obligations of the seller in a sale and purchase agreement, are as follows: Submit ownership rights for the goods being sold. Obligation to bear the peace of mind and bear hidden defects (vrijwaring, warranty). Seller rights generally determine the payment price for the sale of goods from consumers. The right to receive payments in accordance with the 
agreement regarding the conditions and exchange value of goods and / or services being traded. The right to obtain legal protection from consumer actions in good faith. The right to defend oneself properly in the settlement of consumer disputes. The right to rehabilitate a good name if it is not legally proven that consumer losses have not resulted from the goods and / or services being traded. [19]

In buying and selling online, before the buyer agrees about the item, first look at the picture of the item displayed by the seller. After that, ask in detail about whether the goods are genuine or not and so on. Here there is a meeting of the will, namely the offer and acceptance (which is called acceptance) between the buyer and the seller. In this case the buyer wants the goods as desired and agrees to the price set by the pelapak. The seller undertakes the buyer's will and will send the goods according to the buyer 's desired. The buyer's intention has been expressed or expressed to the seller via electronic communication between the two parties where the latter complies with the buyer's request. Thus there has been an agreement regarding the goods and prices that have been listed. Nieuwenhus said that "Will statements that result in an agreement are distinguished between offer (aanbod, offerre) and acceptance (aanvaarding, acceptatie). The offer is formulated as a statement of intention containing a proposal to enter into an agreement to be closed.[20]

An online agreement is formed through an electronic communication process that takes place between the sender and the recipient of the electronic message. To ensure that the electronic message sent by the sender is accepted by the recipient, the recipient must respond by sending a reply message to the sender to notify that the recipient has received the electronic message. This notification is important because without notification by the recipient, the sender cannot confirm whether the electronic message has been received by the recipient. The time of sending electronic messages is that at the time the electronic message enters the information system which is basically beyond the control of the sender of the message. Meanwhile, the time of receiving an electronic message is when the message is entered into the recipient's information system.[21] As for the process of buying and selling online in terms of online bidding and acceptance, it is no different from the process of bidding and receiving in general. Cancellation of the agreement can also be done if there is fraud committed by the online seller. Nieuwenhus said that "Fraud is a qualified form of heresy, it is said that there is fraud if the wrong pictures of the characteristics and circumstances (heresy) are caused by the intentionally misleading behavior of the opponent or his representative."[20]

Consumer protection in the field of private law is mostly found in BW, especially in Book III concerning engagements, such as provisions regarding default (Article 1243 to Article 1252) as well as provisions concerning agreements born due to agreements (Articles 1313 to 1351) and engagements born from law - Laws (Articles 1351 to 1369), especially acts of violation of the law as regulated in Article 1365 to Article 1369.[22] The occurrence of default by the debtor in an agreement has unpleasant consequences for the debtor, because the debtor must: compensate for losses; objects that become the object of the engagement, since the default is borne by the debtor's claim; If the agreement arises from a reciprocal engagement, the creditor can ask for cancellation (termination) of the agreement.[22]

Provisions that specifically regulate electronic transactions are regulated in Law Number 19 Year 2016 concerning Amendments to Law Number 11 Year 2008 concerning Electronic Information and Transactions (ITE Law). As an effort to provide protection to consumers, the Operation of Electronic Systems according to the provisions of Article 15 of the ITE Law states that: Every Electronic System Operator must operate an Electronic System reliably and safely and be responsible for the proper operation of the Electronic System; Electronic System Operator is responsible for its Electronic System Operation; The provisions as intended in paragraph (2) do not apply in the event that it can be proven that a situation forces an error and / or negligence on the part of the Electronic System user.

Then in Article 16 it is stated that:

(1) To the extent that a separate law does not specify otherwise, every Electronic System Operator is obliged to operate an Electronic System that meets the following minimum requirements:

a. can redisplay Electronic Information and / or Electronic Documents in full in accordance with the retention period stipulated by Legislation;

b. can protect the availability, integrity, authenticity, confidentiality and accessibility of Electronic Information in the Operation of Electronic Systems;

c. can operate in accordance with the procedures or instructions in the Operation of Electronic Systems; 
d. equipped with procedures or instructions that are announced in a language, information, or symbols that can be understood by the party concerned with the Operation of Electronic Systems; and

e. has a sustainable mechanism to maintain the novelty, clarity and accountability of procedures or instructions.

(2) Further provisions regarding Electronic System Operation as intended in paragraph (1) shall be regulated by Government Regulation.

To provide protection for consumers due to the actions of online sellers who do not include data and information on merchandise traded online. the Law Number 7 of 2014 concerning Trade in Article 65 it has been determined that: Every Business Actor who trades goods and / or services using an electronic system is required to provide complete and correct data and / or information; Every Business Actor is prohibited from trading goods and / or services using an electronic system that is inconsistent with the data and / or information as referred to in paragraph (1); (2) The use of electronic systems as referred to in paragraph (1) must comply with the provisions stipulated in the Law on Electronic Information and Transactions; (2) Data and / or information as referred to in paragraph (1) shall at least contain: the identity and legality of Business Actor as producer or Distribution Business Actor; the technical requirements of the goods being offered; technical requirements or qualifications of the services offered; prices and payment methods for goods and / or services; and how to deliver the goods.

To regulate trade transactions through this electronic system, a Government Regulation (PP) Number 80 of 2019 concerning Trading Through Electronic Systems has also been issued. In Article 1 paragraph (2), it is stated that "Trading through Electronic Systems, hereinafter abbreviated as PMSE, is a trade whose transactions are carried out through a series of electronic devices and procedures." Then in paragraph (6) it is stated that "Trading Business Actors through Electronic Systems, hereinafter referred to as Business Actors, are any individual or business entity in the form of a legal entity or non-legal entity which can be in the form of Domestic Business Actors and Foreign Business Actors and conducting activities. PMSE business. " Furthermore, in paragraph (11) it is stated that "Trade Operators through Electronic Systems (PPMSE) are Business Actors providing Electronic Communication facilities used for Trading transactions."
In an effort to provide protection to consumers, in PP No.80 / 2019 PMSE Article 13 paragraph (1) it is stated that in every PMSE, Business Actors are required to: provide true, clear, and honest information about the identity of legal subjects supported by data or valid documents; convey true, clear, and honest information regarding the conditions and guarantees of traded Goods and / or Services including Electronic Systems used according to the characteristics of their functions and roles in the transaction; and comply with the requirements of advertising ethics in accordance with the provisions of laws and regulations.

In Article 25 paragraph (1) and (2) PP No.80 / 2019 PMSE it is stated that domestic PPMSE and / or foreign PPMSE are required to keep: PMSE data and information related to financial transactions for a period of at least 10 (ten) years since the data and information were obtained; and PMSE data and information that are not related to financial transactions for a period of at least 5 (five) years from the time the data and information were obtained.

Data and information as referred to in letter $b$, at least concerning: customers; Electronic Offers and Electronic Receipts; Electronic Confirmation; payment confirmation; Goods delivery status; Trade complaints and disputes; Electronic Contracts; and types of goods and / or services being traded.

Article 28 of PP No.80 / 2019 PMSE states that: domestic PPMSE and / or overseas PPMSE are required to provide and keep valid proof of PMSE transactions; Proof of PMSE transactions as referred to in paragraph (1) shall become valid evidence and bind the parties in accordance with the provisions of laws and regulations; PMSE transaction evidence is declared valid if it uses an Electronic System in accordance with the provisions stipulated in the laws and regulations in the field of information and electronic transactions; The provisions referred to in paragraph (2) do not apply to: proof of PMSE transactions which according to the law must be made in writing; and proof of PMSE transactions which according to the law must be made in the form of notary deeds or deeds drawn up by the deed maker official.

Provisions specifically regulating consumer protection are regulated in Law Number 8 of 1999 concerning Consumer Protection (UUPK). In Article 1 number 1 UUPK defines consumer protection as all efforts that ensure legal certainty to provide protection to consumers. H. Ahmad M. Ramli,[23] said that there is a need for further Implementation 
of the definition of consumer protection including online consumer protection by adopting the consumer protection principles of the United Nations (UN) and the Organization for Economic Cooperation and Development (OECD).

In practice, the UUPK has not fully protected consumers in electronic transactions. the UUPK has not regulated further implementation of the definition of consumer protection which includes online consumer protection, the right to information that must be provided to consumers via online media to prevent fraudulent acts, misuse of payment cards belonging to others, the responsibilities of business actors which include responsibility answer to the ISP (Internal Service Provider), the burden of electronic proof, and resolve disputes through information technology facilities. Regarding the problem of dispute resolution in electronic transactions, there is a tendency to choose an arbitration forum.

Consumer rights regulated in Article 4 UUPK are: the right to comfort, security and safety in consuming goods and / or services; the right to choose goods and / or services and to obtain these goods and / or services in accordance with the exchange rate and conditions as well as the promised guarantee; the right to correct, clear and honest information regarding the condition and guarantee of goods and / or services; the right to have their opinions and complaints heard about the goods and / or services used; the right to get advocacy, protection, and proper consumer protection dispute resolution efforts; the right to receive consumer guidance and education; the right to be treated or served correctly and honestly and not to discriminate; the right to get compensation, compensation and / or replacement, if the goods and / or services received are not in accordance with the agreement or not as it should be; rights regulated in the provisions of other laws and regulations.[24]

The UUPK contains a number of prohibitions for business actors as stipulated in Article 9 of the UUPK which states that: Business actors are prohibited from offering, promoting, advertising goods and / or services incorrectly, and / or as if: the goods have met and / or have discounts, special prices, certain quality standards, certain styles or fashions, certain characteristics, history or certain uses; the goods are in good condition and / or new; the said goods and / or services have obtained and / or have had sponsorship, approval, certain equipment, certain benefits, certain work characteristics or accessories; the said goods and / or services are made by a company that has a sponsor, approval or affiliation; the goods and / or services are available; the goods do not contain hidden defects; the goods are completeness of certain goods; the goods come from certain areas; directly or indirectly degrading other goods and / or services; use excessive words, such as safe, harmless, does not contain risks or side effects without complete description; offer something that carries uncertain promise. (2) The goods and / or services as referred to in paragraph (1) are prohibited from being traded. Business actors who violate paragraph (1) are prohibited from continuing the offer, promotion and advertisement of the said goods and / or services.

\subsection{Consumer Dispute Resolution Mechanisms in Online Buying and Selling}

In Trade Law No. 7/2014 emphasized for each seller to provide complete data and information regarding traded goods. If the seller does not provide incomplete data and information about the goods which results in consumer losses, then the dispute settlement between the seller and the buyer can be resolved in court or through other dispute resolution mechanisms such as arbitration and mediation. In full Article 65 paragraph (5) of Law Number 7 of 2014 concerning Trade states that "In the event of a dispute related to trade transactions through an electronic system, the person or business entity experiencing a dispute can resolve the dispute through a court or through a dispute resolution mechanism. other. "

Dispute settlement regulated in Article 45 UUPK determines two options between consumers and business actors through a court that is within the general court or outside the court. However, the process of litigation in court is less attractive to the public, such as disputes in online buying and selling, because the value of consumer losses is relatively small and is not worth the costs incurred for litigating. The impression so far is that the settlement of cases in court takes a long time and costs are not cheap.

The mechanism for resolving consumer disputes based on the aforementioned provisions can be carried out through the general court and outside the court such as arbitration and mediation. With the issuance of the Supreme Court Regulation (Perma) No. 4 of 2019 concerning Amendment of Perma No. 2 of 2015 concerning Procedures for Simple Lawsuit Resolution, the easier it is for the public to sue in court. This is in line with the principles of cheap, fast and simple justice. Simple Claim Settlement is the 
procedure for examination in court against a civil suit with a maximum value of Rp. 500,000,000.00 (five hundred million rupiah), which is examined by a single judge appointed by the Chief Justice. In this simple lawsuit is filed against cases of breach of contract and / or acts against the law. The settlement of this simple lawsuit is no later than 25 (twenty five) days from the day of the first trial. It is not enough for the Supreme Court to issue only simple lawsuit regulations but also to make breakthroughs in administrative examinations in the judiciary through information technology with the issuance of Perma No. 3 of 2018 concerning Electronic Case Administration in Courts. What is meant by Electronic Case Administration at Court is a series of processes for accepting claims / requests, answers, replications, duplicates and conclusions, management, submission and storage of civil / religious case documents / military administration / state administration using the applicable electronic system. in each court environment.

So, the settlement of default disputes in court with the issuance of Perma No.4 / 2019 has made examinations in court simple, fast and inexpensive. Consumers who are disadvantaged by the seller in buying and selling online because of default, usually the value of the loss is below 500 million rupiah. Consumers who suffer losses can take legal action through the court with this simple lawsuit. The issuance of Perma No.3 / 2018 makes it easier for parties to administer cases in court. It is enough to send it electronically through a predetermined site so that you can avoid physical contact with officers during the Covid-19 pandemic. With the application of information technology, litigation time will be reduced from the specified 25 days. According to the author, to avoid the transmission of Covid-19 in court, it is not enough just to administer it electronically, but it is necessary to amend Perma No.3 / 2018 which allows examination in a simple lawsuit to be carried out in vitual or e-court. This simple claim examination is called a small claim court.

Outside the general court UUPK made a breakthrough by facilitating consumers who feel disadvantaged by filing a lawsuit against business actors outside the court, namely the Consumer Dispute Resolution Agency (BPSK). The lawsuit mechanism is carried out voluntarily from both parties to the dispute. This applies to individual claims, while class action cases are carried out through general courts. BPSK is a special consumer court which is expected to be able to answer the demands of the community so that the litigation process can run quickly, simply and cheaply. Thus, BPSK only accepts cases with small losses. The examination is carried out by a single judge and the full presence of a third party (lawyer) as a representative of the disputing party is not permitted. Decision from BPSK cannot be compared unless they are contrary to applicable law.[25]

In UUPK No. 8/1999 states that the Consumer Dispute Resolution Agency is an agency in charge of handling and settling disputes between business actors and consumers. According to the provisions of Article 49 of the UUPK, BPSK is established in a Level II Region. In order to be appointed as a member of a consumer dispute settlement agency, a person must meet the following requirements: a. citizens of the Republic of Indonesia; b. able-bodied; c. good behavior; d. never been convicted of a crime; e. have knowledge and experience in the field of consumer protection; f. be at least 30 (thirty) years old. These members consist of elements from the government, elements of consumers, and elements of business actors. The number of members of each element is at least 3 (three) people and a maximum of 5 (five) people. The appointment and dismissal of members of the consumer dispute settlement agency shall be determined by the Minister. The duties and powers of BPSK according to the provisions of Article 52 UUPK include, among others: carrying out the handling and settlement of consumer disputes, by means of mediation or arbitration or conciliation.

Alternative Dispute Resolution means settling disputes outside of the courtroom. In the general provisions of Article 1 of Law no. 30 of 1999 concerning Arbitration and Alternative Dispute Resolution defines Arbitration as a way of resolving a civil dispute outside the general court based on an arbitration agreement made in writing by the disputing parties. From this definition, it can be concluded that the form of arbitration is not appropriate in settling online buying and selling disputes. This is because the online buying and selling agreement is only in the form of an offer and acceptance in the form of informal internet conversations. Meanwhile, the settlement in the form of arbitration must first have a formal agreement wherein the agreement has determined the choice of the institution if a dispute arises between the parties. Whereas Alternative Dispute Resolution in Article 1 of the Arbitration Law and APS defines "dispute resolution institutions or differences of opinion through procedures agreed by the parties, namely settlement outside the court by means of 
consultation, negotiation, mediation, conciliation, or expert judgment."

The Arbitration Law and the APS do not provide a formulation or explanation regarding the meaning of consultation. If we look at the Black's Law Dictionary, we can see that what is meant by consultation is: "act of consulting or conferring; e.g. patient with doctor, client with lawyer. Deliberation of persons on some subject. " From the formulation given in the Black's Law Dictionary, we can know that in principle, consultation is a personal action between a certain party, which is called a client with another party who is a consultant, who gives his opinion to the client to meet the needs and the needs of these clients.[26]

Regarding what is meant by negotiation, there is also no definition in the Arbitration Law and APS. However, this negotiation can be found in Article 6 which states that disputes or civil differences of opinion can be resolved by the parties through alternative dispute resolution based on good faith by overriding litigation in the District Court (paragraph 1). Settlement of disputes or differences of opinion through alternative dispute resolution as referred to in paragraph (1) shall be resolved in a direct meeting by the parties within a maximum period of 14 (fourteen) days and the results are stated in a written agreement (paragraph 2). So, based on this provision, negotiated dispute resolution is carried out by the parties by meeting in person. The deadline for settling the dispute is no longer than 14 (fourteen) days and if there is an agreement it must be stated in the form of a written agreement.

Mediation is an intermediary procedure in which a person acts as a "vehicle" to communicate between the parties, so that their different views on the dispute can be understood and possibly reconciled, but the main responsibility for achieving a peace remains with the parties themselves.[27] The Black Law Dictionary defines Mediation as: A method of non-binding dispute resolution involving a neutral third party who tries to help the disputing parties reach a mutually agreeable solution.[28]

mediation is set in Article 6 paragraph (3), (4), (5) and (6) of the Arbitration Law and APS. Article 6 paragraph (3) states that in the case of a dispute or difference of opinion that cannot be resolved, one or more expert advisors can be asked for assistance or through a mediator. Then in paragraph (4) it is said that if the parties within a period of 14 (fourteen) days with the help of one or more expert advisors or through a mediator fail to reach an agreement, the parties can contact an arbitration institution or an alternative settlement institution. dispute to appoint a mediator. Furthermore, in paragraph (4) it is stated that after the appointment of a mediator by an arbitration institution or an alternative dispute resolution institution, within a maximum period of 7 (seven) days the mediation effort must be started. Then, in paragraph (6) it is stated that within a period of 30 (thirty) days an agreement must be reached in writing signed by all parties concerned.

The forms of non-litigation dispute resolution regulated in the Arbitration Law and APS must be carried out through a meeting with the attendance of the disputing parties. Bringing together the disputing parties under normal circumstances would not be a problem. But in the midst of the Covid-19 pandemic that is hitting the world, of course, meetings with the presence of the parties must be avoided in order to reduce transmission of the Covid-19 virus. Therefore, it is necessary to propose to make derivative rules from the Arbitration Law and APS which in resolving consumer disputes in online buying and selling and banking services can be done virtually. Through this information technology approach, it will be able to help resolve consumer disputes more efficiently without the need to physically come to the designated meeting place. The process of examining the mediator is virtually because the results of the parties' agreement are mutually binding on both parties.

\subsection{Banking Dispute Resolution via Virtual}

The banking business in Indonesia is one of the financial services industries that continues to develop, in line with the rapid development of information technology. Especially with the presence of financial technology, this industry is increasingly becoming the main pillar of national sources of financing. However, these conditions certainly also increase the risk of various kinds of national and international business disputes between customers as consumers and bank companies. Thus, a credible institution supported by a judicial system that is fast, precise, and low cost is needed. Article 6 paragraph (1) of Law Number 30 of 1999 concerning Arbitration and Alternative Dispute Resolution, states: Disputes or civil differences of opinion can be resolved by the parties through alternative dispute resolution based on good faith by overriding litigation in the District Court.

Alternative business dispute resolution between the bank company and its customers, can be resolved out of court (non-litigation) through mediation, in accordance with Law Number 30 of 1999. If the 
dispute cannot be resolved through mediation, it must be proceeded to court. Various banking cases, such as: protection of customer savings, credit-cards, deposit insurance insurance, default, claims rejected, problems in borrowing and borrowing money (creditors-debtors), buying and selling agreements that even involve other countries and banking services, etc., are examples of cases that can be submitted to the mediation institution. In accordance with Law No. 10 of 1998 concerning banking in conjunction with OJK Regulation No. 1/2013 concerning Consumer Protection in the Financial Services Sector, stipulates that: all banking sectors and finance companies are required to have an Alternative Dispute Resolution Institution (LAPS). The presence of alternative dispute resolution body has an important role in development of dispute settlement system. The parties have another option other than litigation. The exercise of case by virtual must be developed to anticipate the restriction of people's movement especially during the Covid-19 pandemic.

There are several mediation institutions that can be alternative options for resolving civil business disputes, including: The Alternative Institute for Indonesian Banking Dispute Resolution (LAPSPI). Is a dispute resolution institution that can be an alternative for consumers who have problems with a dispute that is not too large. The agency's services are completely free, so consumers don't need to be bothered with handling in court. The results of this LAPSPI decision are binding on both parties, but if consumers are not satisfied, they must take them to court. This institution was founded by 6 banking associations namely: the National Commercial Bank Association (Perbanas), the Regional Development Bank Association (Asbanda), the Indonesian People's Credit Bank Association (Perbarindo), the Indonesian Sharia Bank Association (Asbisindo), and the Foreign Bank Association (Perbina).

Its vision is to become a professional, fair, trustworthy Alternative Dispute Resolution Institution, and the main choice of customers and banks in resolving banking disputes. Imagine the mission is to provide alternative services for dispute resolution that are fair, fast, cheap, and efficient; Provide a dispute resolution service scheme that is easily accessible to consumers; To provide Mediators, Adjudicators and Arbitrators who are competent, credible and have integrity; Implement good governance in accordance with the principles of transparency, accountability, responsibility, independence and fairness; Encouraging the banking industry and the public to use LAPSPI as the main alternative dispute resolution institution.

Core values: Trust; Trustworthy and meet expectations; Always prioritizing the best work; Integrity; Act consistently in accordance with the rules, policies, procedures and Code of Ethics of the Institution; Reputable: Having professional Mediators, Adjudicators and Arbitrators; Consistently run fast, cheap, effective and efficient processes; Make decisions that are neutral / impartial, rational, and fair; Implement good governance. Independence: Free from intervention of other parties; and Free from Conflict of Interest.

The principles of dispute resolution are: Easy to access; Cheap; Fast; Performed by human resources who are competent and understand the financial services industry. Based on the Financial Services Authority Regulation Number 1 / POJK.07 / 2014 concerning Alternative Institutions for Dispute Resolution in the Financial Services Sector, LAPS has the following principle: firstly, The principle of accessibility. Dispute resolution services are easily accessible to consumers and cover all of Indonesia. Secondly, Principle of independence. LAPS has a supervisory organ to maintain and ensure the independence of LAPS human resources. In addition, LAPS also has adequate resources so that it does not depend on certain Financial Services Institutions. Thirdly, The principle of justice. The mediator at LAPS acts as a facilitator in order to bring together the interests of the parties in obtaining a dispute resolution agreement, while the adjudicator and arbitrator are required to provide written reasons in each of their decisions. If there is a refusal of a request for dispute resolution from the consumer and the Financial Service Institution, LAPS is obliged to provide a written reason. Lastly, The principle of efficiency and effectiveness. Low cost to consumers in dispute resolution. Dispute resolution at LAPS is done quickly. The implementation of decisions is supervised by LAPS.

The stages of dispute resolution are: Preliminary analysis carried out with the following stages: Requesting documents and / or information to LAPS; Verification to LAPS (if needed); LAPS document and or information processing; and Formulation of analysis results on LAPS documents and or information; Testing of compliance with LAPS requirements. The LAPS testing team consists of seven people from internal and external OJK, based on the weighting and assessment scale as stipulated in the OJK Circular regarding Guidelines for Assessment of Alternative Dispute Resolution 
Institutions in the Financial Services Sector. The determination of the results of the assessment is classified into two, namely: Qualified if the score is at least 75 (seventy five) and there is no zero value in the LAPS requirement component; or have not met the requirements if the score is less than 75 (seventy five) or there is a zero value in the LAPS requirement components.

Dispute resolution fees at LAPS, vary depending on the type of dispute resolution service selected and the amount of financial dispute. For dispute resolution by mediation, LAPS usually does not charge a fee. Whereas for adjudication and arbitration, a certain percentage of the disputed financial loss is usually determined. However, each LAPS has different provisions regarding dispute resolution costs, for example BMAI does not charge fees for dispute resolution with the amount of claims for compensation or policy benefits disputed not exceeding IDR 750 million / claim for general or general insurance and IDR 500 million / claim for life insurance or social security insurance.

Currently LAPS in the financial services sector is only in Jakarta. For dispute resolution in the regions, LAPS will usually go to the area where the consumer is located or on the other hand, LAPS will bring the parties to Jakarta. In the event that dispute resolution is carried out in the regions, it can be done at the nearest Regional Office or OJK Office or other places according to the agreement. In serving dispute resolution throughout Indonesia, LAPS in the financial services sector does not have to have offices in every region of Indonesia. However, these institutions can provide services by utilizing information technology, including teleconferencing or video conferencing tools. LAPS has the freedom to implement OJK policies in order to be able to serve dispute resolution in all regions of Indonesia, for example by visiting the disputing actors, in accordance with OJK Regulation Number 1 / POJK.07 / 2014 concerning LAPS and OJK Circular Letter Number 7 / SEOJK.07 / 2015 regarding the LAPS Assessment Guidelines.

Muhamad Djumhana [29], argues, that the guarantee of the confidentiality of all public data in relation to the bank, the public will trust the bank, and entrust their money to the bank or use bank services. Public trust will be borned when the bank guarantees that the bank's knowledge of customer deposits and financial conditions will not be misused. Law No.10 of 1998 concerning banking, mandates the establishment of a Deposit Insurance Corporation and requires each bank to guarantee public funds deposited in the bank concerned, as stipulated in Law Number 7 of 2009. Banking consumer protection in general can also be found in Law Number 8 of 1999 concerning Consumer Protection (Law No.8 / 1999). This has logical consequences for banking services, in order to: Have good faith in carrying out business activities; Provide true, clear and honest information regarding the conditions and guarantees of the services it provides; Treating or serving consumers properly and honestly and not discriminatory; Guaranteeing banking business activities based on the applicable banking standards; etc. Law No. 8 of 1999 protects bank customers by limiting standard clauses set by the bank (Article 18).

The non-litigation route, Alternative Dispute Settlement (ADS) can virtually be an alternative option for dispute resolution, because the cost is relatively cheaper than using the litigation route. Especially for banking problems, the middle ground method has started with BI Regulation No.7 / 7 / PBI / 2005. Then changed to No.8 / 5 / PBI / 2006, and improved by Regulation No.10 / 1 / PBI / 2008. In essence, there is an opportunity for mediation between the Bank and the customer where Bank Indonesia facilitates this mediation, for a maximum financial demand value of $\mathrm{Rp} 500$ million. In addition, the customer or complainant is also not in process or has received a decision from an arbitration institution, judiciary or other mediation institution, has attempted resolution by the bank (through the customer complaint mechanism), and has never been processed in a banking mediation facilitated by Bank Indonesia. . In the case of credit card dispute resolution, the bank should urge customers to be more careful in maintaining their credit card, and when their credit card is lost, the customer should immediately report to the bank concerned to immediately block / deactivate the credit card. Given the development of information technology in the banking business, as well as the current global situation and conditions, especially in the era of the Covid-19 pandemic, it is time for a legal breakthrough to resolve civil business disputes, both nationally, especially in the global sphere, through virtual.

\section{CONCLUSION}

Various cases have occurred in recent times, such as: online buying and selling, customer savings protection, credit-cards, deposit insurance, default, claims denied, problems of borrowing and borrowing money (creditors-debtors), sales 
agreements -buy goods that even involve other countries and banking services, etc., are examples of cases that can be submitted to the mediation institution. The banking business in Indonesia is one of the financial services industries that continues to develop, in line with the rapid development of information technology. Especially with the presence of financial technology, this industry is increasingly becoming the main pillar of national sources of financing. However, these conditions certainly also increase the risk of various kinds of national and international business disputes between customers as consumers and bank companies.

To settle cases, these disputes, apart from going through formal channels, courts (litigation), need to be pursued by alternative legal options for a credible institution supported by a judicial system that is fast, precise, and low cost, ADR as regulated in Law Number 30 of 1999 concerning Arbitration and Alternative Dispute Resolution. Alternative business dispute resolution between the bank company and its customers, can be resolved by mediation, in accordance with Law No. 10 of 1998 on banking in conjunction with OJK Regulation No. 1/2013 concerning Consumer Protection in the Financial Services Sector, stipulates that: all banking sectors and finance companies are required to have an Alternative Dispute Resolution Institution (LAPS). The presence of financial dispute resolution mediation institutions through virtual, is an answer to the problem of dispute resolution, can be an alternative option, because the cost is relatively cheaper, easy, efficient, than using litigation. especially during the Covid-19 pandemic.

\section{AUTHORS' CONTRIBUTIONS}

All authors have the same rights, obligation and contribution to the proportion, use and utilization of this paper.

\section{REFERENCES}

[1] hukumonline.com, "risiko-hukum-belanjaonline-di-masa-pandemi." .

[2] Kompas, "Transaksi Belanja Online Meningkat, Mendag Minta UMKM Masuk ke Market Digital.".

[3] Pikiran Rakyat, "Belanja Online Meningkat 400 Persen, BPKN : Masih Banyak Dikeluhkan Konsumen.”.

[4] “Tertipu Belanja Online Ngadunya Kemana," detik.com.
[5] Kompas, "Toko online paling banyak diadukan konsumen ke YLKI.”.

[6] Infokomputer.grid.id, “Apa itu sistem keamanan one time password OTP." .

[7] S. Sunarso, Information Law and Electronic Transactions: Prita Mulyasari case study. Jakarta: Rineka Cipta, 2009.

[8] “istilah-marketplace-e-commerce-danjualan-online.".

[9] "shop-marketplace-dan-e-commerce-apabedanya." .

[10] "pengertian-e-commerce." .

[11] I Putu Agus Eka Pratama, E-Commerce, EBusiness dan Mobile Commerce. Bandung: Informatika Bandung, 2015.

[12] Chandra Ahmadi dan Dadang Hermawan, E-Business \& E-Commerce. Yogyakarta: Andi, 2013.

[13] "peluang-bisnis-2020-bisnis-ecommerceakan-memasuki-tahun-emas.” .

[14] "perbedaan-perikatan-perjanjian-dankontrak/.".

[15] J. Satrio, Agreement Law. Bandung: Citra Aditya Bakti, 1992.

[16] “aspek-hukum-bisnis-ecommerce." .

[17] hukumonline.com, "batalnya-suatuperjanjian.".

[18] Mila Nila Kusuma Dewi, "Dispute Resolution in Online Purchase and Purchase Agreements," Cahaya Keadilan, vol. 5 No. 2, hal. 78, 2017.

[19] Yudha Sri Wulandari, "Legal Protection for Consumers of E-Commerce Buying and Selling Transactions," J. Ilmu Huk., vol. 2 No.2, hal. 199-210, 2018.

[20] Abdul Halim Barkatullah and Teguh Prasetyo, E-Commerce Business: A Study of Security and Legal Systems in Indonesia. Yogyakarta: Student Library, 2006.

[21] A. Yaqin, "Due to Default Law in Online Buying and Selling According to the Law on Electronic Information and Transactions," Din. J. Leg. Sci., vol. 25 No.26, hal. 14, 2019.

Ahmadi Miru, Principles of Legal 
Protection for Consumers in Indonesia. Jakarta: Rajawali Pers, 2013.

[23] H. Ahmad M. Ramli, Cyber Law and HAKI in the Indonesian Legal System. Bandung: Refika Aditama, 2010.

[24] Rizka Syafriana, "Consumer Protection in Electronic Transactions," Lega Lata, vol. 1 No. 2, hal. 433, 2016.

[25] Celina Tri Siwi Kristiyanti, Consumer Protection Law. Jakarta: Sinar Grafika, 2016.

[26] Gunawan Wijaya, Alternative Dispute Resolution. Jakarta: RajaGrafindo Persada, 2002.

[27] Frans Hendra Winarta, Indonesian and International National Arbitration Dispute Resolution Laws. Jakarta: Sinar Grafika, 2011.

[28] Black Law Dictionary, Eight Edit. West Publishing Co, 2004.

[29] M. Djumhana, Banking Law in Indonesia. Bandung: PT Citra Aditya Bakti, 2012. 